\title{
IN VITRO STUDIES ON CALCIUM OXALATE CRYSTAL GROWTH INHIBITION OF STROBILANTHES CRISPUS EXTRACTS
}

\author{
Afrizal Itam ${ }^{1}$, Zhari Ismail ${ }^{2}$ and Amin Malik Shah Abdul Majid ${ }^{2}$ \\ ${ }^{1}$ Chemistry Department of Mathematic and Natural Sciences Faculty, \\ Andalas University, Padang, Indonesia \\ ${ }^{2}$ School of Pharmaceutical Sciences, Universiti Sains Malaysia, \\ 11800 Minden, Penang, Malaysia
}

\begin{abstract}
Strobilanthes crispus L. (Acanthaceae) has been used locally in traditional medicine for kidney stone and related diseases. These plant extracts have the ability to inhibit the calcium oxalate crystal growth, where the ability of water extract is higher than those of the $70 \%$ acetone, methanol and acetone extracts. The ability to inhibit the calcium oxalate crystal growth of these extracts is lower than that of sodium citrate as positive control.
\end{abstract}

Keywords: Strobilanthes crispus, Acanthaceae, crystal inhibition, calcium oxalate

\section{REFERENCES}

1. Departemen Kesehatan Republik Indonesia, Materia Medika Indonesia, Jakarta,, 1: 9599,(1997).

2. S. S. Syamsuhidayat dan J. R. Hutapea, Inventaris Tanaman Obat Indonesia, Departemen Kesehatan RI, Jakarta, 1991, 1: 286-287.

3. H. Wijayakusuma, S. Dalimartha, dan A. S. Wirian, Tanaman Berkhasiat Obat di Indonesia, Pustaka Kartini, Jakarta, 2000, 1: 71-73.

4. K. Heyne, Acanthaceae; Strobilanthes crispus, BL., Tumbuhan Berguna Indonesia III, Badan Litbang Kehutanan, Jakarta edition : Yayasan Sarana Wana Jaya, Jakarta, 1987, 1752-1754.

5. L. M Perry and J. Metzger, Medicinal Plants of East and Southeast Asia,
Cambridge, Massachusetts, London, England: Massachusetts Institute of Technology, 1980, 620.

6. I. Soediro, J. Pellcuer, C. Andary, and G. Privat, Strobilanthes crispus, (L) BL. Isolation and Identification of the caffeic acid derivative, verbascoside, 99: 50302q, Acta Pharmaceutica Indonesia, 8: 1-10, (1983).

7. I. Soediro, J. Pellcuer, C. Andary, and G. Privat, Identification of phenolic acid in Strobilanthes crispus (L) BL., 108: 147193x, Acta Pharmaceutica Indonesia, 12: 1-7, (1988).

8. Departemen Kesehatan Republik Indonesia Materia Medika Indonesia, Jakarta, 4: 5762, (1980).

9. H. J. Schneider, W. Bothor, W. Berg, R. H. Borner, and M. Jakob, A Gel Model for Measuring Crystallization Inhibitor, Urology International, 38: 33-38, (1983). 